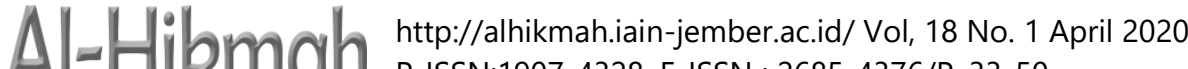

\section{Nilai Filosofi Wayang Kulit Sebagai Media Dakwah}

\author{
Eko Setiawan \\ Universitas Brawijaya Malang \\ oke.setia@gmail.com
}

\begin{abstract}
When the teachings of Islam were spread on the island of Java, the majority of people who still embraced Hinduism had a fondness in watching the wayang performances. Historically, the wali songo using cultural approach and plays a major role in the development of wayang in Indonesia. In addition to using wayang as a medium of propaganda, also through various forms of other cultural acculturation for example through the creation of Javanese Islamic songs, gamelan, and Islamic story. In wayang kulit performances bring a lot of influence for the Java community because it contains many philosophy of life and values of the noble. The wayang culture, which continues to evolve from time to time, is also a medium of information, da'wah, education, entertainment, philosophical understanding, as well as entertainment, as well as the philosophical value embodied in puppet always invites society to do good and avoid crime.
\end{abstract}

Keywords: Philosophy Value, Wayang Kulit, Da'wah Media

\begin{abstract}
Abstrak
Ketika ajaran Islam disebarkan di Pulau Jawa, masyarakat yang sebagian besar masih memeluk agama Hindu memiliki kegemaran menonton pagelaran wayang. Dalam sejarahnya para wali berdakwah dengan menggunakan pendekatan budaya dan berperan besar dalam pengembangan pewayangan di Indonesia. Di samping menggunakan wayang sebagai media dakwahnya, juga melalui berbagai bentuk akulturasi budaya lainnya contohnya melalui penciptaan tembang-tembang keislaman berbahasa Jawa, gamelan, dan lakon Islami. Dalam pementasan wayang kulit banyak membawa pengaruh bagi masyarakat Jawa karena banyak mengandung falsafah kehidupan dan tata nilai yang luhur. Budaya wayang, yang terus berkembang dari zaman ke zaman, juga merupakan media penerangan, dakwah, pendidikan, hiburan, pemahaman filsafat, serta hiburan, serta nilai falsafah yang terkandung dalam pewayangan selalu mengajak masyarakat untuk berbuat baik dan menghindari kejahatan.
\end{abstract}

Kata Kunci: Nilai Filosofi, Wayang Kulit, Media Dakwah 


\section{Pendahuluan}

Masyarakat Jawa mempunyai kekayaan budaya, salah satunya pertunjukan pagelaran wayang dengan kemahiran sang dalang, dapat menyajikan berbagai macam pengetahuan, filsafat hidup berupa nilai-nilai hidup dan budaya serta berbagai unsur seni budaya yang terpadu dalam seni pendalangan. Pertunjukan wayang kulit yang didalamnya terdapat perpaduan antara suara, seni musik (gamelan) dan seni rupa, merupakan bentuk kesenian yang sangat disukai masyarakat Jawa. Kesenian wayang kulit adalah salah satu kesenian yang telah ada di Indonesia sejak ajaran Hindu masih tersebar di seluruh Nusantara. Wayang sendiri mengambil tokoh-tokoh Dewa maupun Ksatria yang ada dalam agama Hindu dari India dan seni pertunjukkan asli Indonesia yang berkembang pesat di Pulau Jawa. Pada tanggal 7 November, UNESCO sebagai lembaga yang membawahi kebudayaan dari PBB, menetapkan wayang sebagai pertunjukkan bayangan boneka tersohor dari Indonesia, sebuah warisan mahakarya dunia yang tak ternilai dalam seni bertutur (Masterpiece of Oral and Intangible Heritage of Humanity). Pertunjukan wayang di Indonesia memiliki gaya tutur bahasa dan keunikkan tersendiri, yang merupakan mahakarya asli dari Indonesia. Dan untuk itulah UNESCO memasukannya ke dalam daftar warisan dunia.

Wayang kulit merupakan sebuah boneka tiruan yang terbuat dari pahatan kulit sapi atau kerbau, yang dapat dimanfaatkan untuk memerankan tokoh dalam pertunjukan dan biasanya dimainkan oleh seseorang yang disebut dalang. Selain itu wayang didefinisikan sebagai boneka atau penjelmaan dari manusia yang terbuat dari kulit kerbau atau sapi. Wayang kulit adalah bentuk kesenian yang menampilkan adegan drama bayangan boneka yang terbuat dari kulit binatang, berbentuk pipih, diwarna dan bertangkat ${ }^{1}$. Ada juga yang mengartikan bahwa perkataan wayang berasal dari bahasa Jawa, yang artinya perwajahan yang mengandung penerangan. Wayang kulit merupakan salah satu bentuk teater tradisional yang paling tua di Indonesia. Pada masa pemerintahan Raja Balitung pertunjukan wayang telah ada, hal tesebut ditemukan pada prasasti Balitung tahun 907 Masehi, yang berbunyi "si galigi mawayang". Sejarah perkembangan seni wayang di Indonesia, yaitu pada abad ke 4 orang-orang Hindu datang ke Indonesia, melalui jalur perdagangan. Pada kesempatan tersebut orang-orang Hindu membawa ajarannya dengan Kitab $\mathrm{Weda}^{2}$ dan epos cerita dari India yaitu Mahabharata dan Ramayana dalam bahasa Sanskrit. Kemudian pada abad 9, bermunculan ceritacerita dengan bahasa Jawa kuno dalam bentuk kakawin yang bersumber dari cerita

${ }^{1}$ Setyo Budi. Wayang-Wayang Katolik Surakarta: Spesifikasi dan Karakteristiknya. (Bandung: Proyek Penelitian Pendidikan Tinggi Direktorat Jenderal Pendidikan Tinggi Departemen Nasional, 2002).

${ }^{2}$ Weda secara ethimologinya berasal dari kata "Vid" (bahasa sansekerta), yang artinya mengetahui atau pengetahuan. Weda adalah ilmu pengetahuan suci yang maha sempurna dan kekal abadi serta berasal dari Hyang Widhi Wasa. 
Mahabharata atau Ramayana, yang telah diadaptasikan dengan kebudayaan Jawa. Demikian juga saat masuknya Islam, ketika pertunjukkan yang menampilkan "Tuhan" atau "Dewa" dalam wujud manusia dilarang, munculah boneka wayang yang terbuat dari kulit hewan, dimana saat pertunjukkan yang ditonton hanyalah bayangannya saja, yang sekarang kita kenal sebagai wayang kulit.

Dalam kesenian wayang kulit terdapat dua entitas penting yang selalu dinamis mengikuti perubahan zaman dan isu yang hangat ditengah masyarakat yaitu sosok dalang dan lakon (tokoh yang diperankan). Dalang sebagai aktor yang memainkan boneka dengan mengarahkan penonton pada sebuah kisah (cerita) yang ingin dituju. Dalang sebagai pengatur jalannya cerita pertunjukan wayang. Dalam pertunjukan wayang kulit, dalang adalah bagian terpenting dan utama. Dalang berasal dari akronim ngudhal piwulang. Kata ngudhal berarti membongkar atau menyebar luaskan dan piwulang berarti ajaran, tuntunan, pendidikan, ilmu, informasi. Jadi fungsi dalang dalam pergelaran wayang kulit bukan saja pada segi pertunjukan atau hiburan, namun juga harus memberi tuntunan dan tontonan. Dalam seni pewayangan merupakan sebuah tuntunan hidup bagi masyarakat Jawa, syarat akan kandungan nilai-nilai luhur yang sampai sekarang masih didambakan ${ }^{3}$. Dalang harus menguasai teknik pedalangan sebagai aspek hiburan, juga berpengetahuan luas dan mampu memberikan pengaruh. Seorang dalang yang hebat, tidak hanya cakap dalam bercerita, akan tetapi juga mampu mengarahkan alur doktrinisasi terhadap penonton serta menggunakan suatu simbol tertentu yang penuh penjiwaan, cipta dan rasa $^{4}$. Sehingga pementasan wayang kulit tidak hanya sebatas hiburan rakyat semata. Lakon sangat dipengaruhi unsur budaya lokal klasik dan budaya luar. Lakon yang dipengaruhi budaya lokal didasarkan pada kisah-kisah leluhur dan hasil kreasi dalang pendahulu, seperti tokoh Semar, Gareng, Petruk dan Bagong. Sedangkan lakon yang berasal dari budaya luar seperti yang dikisahkan dalam kisah Ramayana dan Mahabarata dengan lakon Rama, Rahwana, hingga Pandawa Lima, 100 kurawa dan seterusnya.

Pementasan wayang kulit merupakan salah satu media yang efektif untuk penyampaian pesan moral dan dakwah, etika. Dari zaman kedatangan Islam digunakan para walisongo sebagai sarana media dakwah Islam di tanah Jawa ${ }^{5}$. Wayang kulit mengalami masa kejayaan dimasa lampau, bahkan pada masa penyebaran agama Islam di pulau Jawa, para wali menggunakan cerita dan pertunjukan wayang kulit yang telah disisipi oleh ajaran-ajaran dan kaidah-kaidah Islam sebagai media penyebaran agama Islam, hal ini dapat terwujud karena ceritacerita wayang memiliki cerita yang menggambarkan tentang kehidupan manusia

\footnotetext{
${ }^{3}$ Suwaji Bastomi, Nilai-Nilai Seni Pewayangan, (Semarang: Dahara Prize, 1993), 4.

${ }^{4}$ Ridin Sofwan, Merumuskan Kembali Interelasi Islam-Jawa, (Yogyakarta: Gama Media, 2004), 80 .

${ }^{5}$ Hazim Amir, Nilai-Nilai Etis dalam Wayang, (Jakarta: CV. Mulia Sari, 1991), 16.
} 
yang mengajarkan pada kita untuk menjalani hidup pada jalan yang benar, dimana dalam hal ini agama Islam juga mengajarkan hal yang sama sehingga mudah bagi para wali untuk memasukkan ajaran Islam ke dalam cerita wayang. Metode tersebut terbukti cukup berhasil, karena pada zaman itu, pertunjukan wayang kulit merupakan sarana hiburan bagi rakyat yang dapat merangkul semua kalangan masyarakat luas. Dengan kreatifitas para wali dan melakukan perombakan pada fungsi wayang tanpa menghilangkan nuansa adat istiadat dan kebudayaan masyarakat lokal setempat, perubahan itu dilakukan guna mempermudah penyebaran informasi tentang ajaran agama yang efektif. Wayang dalam perkembangannya di era komunikasi dan informasi pada saat sekarang ini berubah peran menjadi media komunikasi sosial, khususnya dalam menyampaikan aspirasi masyarakat terkait dengan realita sosial.

Seiring dengan perkembangan zaman, wayang kulit mulai tergeser oleh media-media hiburan lain yang lebih modern dan lebih mudah dijangkau oleh masyarakat. Masyarakat modern lebih memilih menghabiskan waktu untuk menonton televisi di ruangan keluarga yang nyaman daripada menghabiskan waktu semalam suntuk untuk menonton pertunjukan wayang yang panjang sampai dini hari, cenderung membosankan, dan ceritanya sulit untuk dimengerti apalagi untuk dinikmati. Kecanggihan teknologi telah melahirkan instrumen-instrumen hiburan baru yang memungkinkan manusia untuk mendapatkan berbagai macam hiburan tanpa perlu keluar rumah. Hal ini membuat masyarakat moderen melupakan kesenian tradisional yang ada di Indonesia salah satunya wayang kulit. Oleh karena itu berdasarkan uraian di atas, mendorong keingintahuan penulis untuk mengkaji lebih jauh tentang sejarah wayang kulit, perlengkapan wayang kulit, makna filosofi wayang sebagai media dakwah.

\section{Sejarah Wayang Kulit}

Secara harfiah dari wayang adalah bayangan, tetap dalam perjalanan waktu pengertian itu berubah, dan kini wayang dapat berarti pertunjukan panggung atau teater atau dapat pula berarti aktor dan aktris ${ }^{6}$. Konon asal usul wayang kulit ini ada dua pendapat. Yang pertama, wayang kulit berasal dan lahir pertama kali di Pulau Jawa, tepatnya di Jawa Timur. Seni wayang amat erat kaitannya dengan keadaan sosiokultural dan kepercayaan masyarakat Indonesia, khususnya orang Jawa. Seperti panakawan, tokoh yang dipandang sangat penting dalam pewayangan, yakni Semar, Gareng Petruk, Bagong, hanya ada dalam pewayangan Indonesia, dan tidak ada di negara lain. Selain itu, nama dan istilah teknis pewayangan, semua berasal dari bahasa Jawa, khususnya Jawa Kuno, bukan dari bahasa lain. Pendapat kedua menduga wayang berasal dari India, yang dibawa bersama agama Hindu ke

${ }^{6}$ Pandam Guritno, Wayang, Kebudayaan Indonesia dan Pancasila, (Jakarta: UI Press, 1988), 11. 
Indonesia. Sebagian besar ahli yang berpendapat bahwa wayang berasal dari India, negara Eropa yang pernah menjajah India.

Sejak tahun 1950, pada buku-buku perwayangan sudah tertulis bahwa wayang berasal dari Pulau Jawa, sama sekali tidak diimpor dari negara lain, khususnya India. Seni perwayangan, khususnya wayang kulit, diperkirakan sudah lahir di Indonesia pada zaman pemerintahan Airlangga, yang memerintah kerajaan Kahuripan (976-1012). Karya sastra Jawa yang menjadi sumber cerita wayang sudah ditulis oleh pujangga Indonesia pada Abad 10, seperti kitab Ramayana kakawin berbahasa Jawa Kuno yang ditulis pada masa pemerint ahan Raja Dyah Balitung (989-910). Kitab ini disinyalir merupakan gubahan dari kitab Ramayana karangan pujangga India, Walmiki. Para puangga tidak lagi hanya menyadur kitabkitab dari mancanegara tetapi sudah mengubah dan membuat karya sastra dengan falsafah Jawa. Wayang kulit mulai di pertontonkan zaman pemerintahan Airlangga. Hal ini bisa dilihat dari beberapa prasasti yang dibuat pada masa itu, yang menyebutkan kata-kata mawayang dan aringgit yang sudah ada menunjuk pada pertunjukan wayang yang dimaksud di sini adalah wayang kulit. Dengan demikian kesenian wayang kulit sudah ada sejak zaman Airlangga dan masih berlangsung sampai saat ini.

Wayang adalah jenis seni pertunjukan yang mengisahkan seorang tokoh atau kerajaan dalam dunia perwayangan. Wayang berasal dari kata Ma Hyang yang berarti menuju kepada roh spiritual, dewa atau Tuhan Yang Maha Esa. Wayang kulit adalah walulang inukir (kulit yang diukir) dan dilihat bayangannya dari kelir ${ }^{7}$. Cerita wayang diambil dari buku Mahabharata atau Ramayana. Kesenian wayang sudah ada di Indonesia sejak zaman kerajaan Hindu. Pada zaman dahulu, wayang merupakan kesenian yang sangat populer. Pada masa pemerintahan raja-raja di Jawa, wayang dipakai sebagai sarana hiburan bagi rakyat. Karena orang Jawa memandang bahwa wayang mengandung filsafat yang dalam dan dan memberi peluang untuk melakukan pengajian filsafat dan ajaran keagamaan ${ }^{8}$. Wayang kulit penuh dengan makna simbolik karena dalam pertunjukannya menggambarkan perjalanan hidup manusia, yakni manusia yang mencari jati diri akan asalnya, bukan manusia yang hanya hidup dan tidak mati. Gambaran yang jelas dapat dilihat dari struktur lakon yang dibawakan oleh dalang yakni menceriterakan perjalanan hidup salah satu tokoh pewayangan ${ }^{9}$.

Wayang kulit sebagaimana adanya sekarang merupakan kreasi wali songo, khususnya Sunan Bonang dan Sunan Kalijaga, dari membaca alam lingkungan masyarakat Jawa yang telah tumbuh sebelumnya, menggunakan wayang guna

${ }^{7}$ Sri Mulyono, Asal-Usul Filsafat dan Masa Depannya, (Jakarta: Gunung Agung, 1976), 154.

${ }^{8}$ Haryanto, Bayang-Bayang Adiluhung, (Semarang: Dahara Prize, 1992), 77.

${ }^{9}$ Solichin Salam, Sekitar Wali Sanga, (Jakarta: Menara Kudus, 1960), 65. 
menyebarkan ajaran Islam. Dengan wayang kulit, sunan Kalijaga berharap pesanpesannya dapat dengan mudah diterima masyarakat yang saat itu sangat menyenangi wayang. Kreatifitas para wali memanfaatkan budaya setempat sebagai media penyebaran Islam yang efektif tersebut, telah mempercepat pertumbuhan dan perkembangan Islam di Jawa. Selain itu para wali juga berjasa dalam mempopulerkan seni wayang sebagai bentuk kesenian pentas yang merupakan salah satu kekayaan budaya Indonesia yang telah berakar jauh ke masa lalu dan cukup banyak mengalami pertumbuhan dan penyempurnaan dari masa ke masa.

Pagelaran wayang kulit dimainkan oleh seorang yang kiranya bisa disebut penghibur publik terhebat di dunia. Bagaimana tidak, selama semalam suntuk, sang dalang memainkan seluruh karakter aktor wayang kulit yang merupakan orangorangan berbahan kulit kerbau dengan dihias motif hasil kerajinan tatah sungging (ukir kulit). Ia harus mengubah karakter suara, berganti intonasi, mengeluarkan guyonan dan bahkan menyanyi. Untuk menghidupkan suasana, dalang dibantu oleh musisi yang memainkan gamelan dan para sinden yang menyanyikan lagu-lagu Jawa. Tokoh-tokoh dalam pewayangan keseluruhannya berjumlah ratusan. Orangorangan yang sedang tak dimainkan diletakkan dalam batang pisang yang ada di dekat sang dalang. Saat dimainkan, orang-orangan akan tampak sebagai bayangan di layar putih yang ada di depan sang dalang. Bayangan itu bisa tercipta karena setiap pertunjukan wayang memakai lampu minyak sebagai pencahayaan yang membantu pemantulan orang-orangan yang sedang dimainkan. Setiap pementasannya selalu di penuhi penonton ${ }^{10}$.

\section{Perlengkapan Wayang Kulit}

Seni memainkan wayang yang biasa disebut pagelaran, merupakan kombinasi harmonis dari berbagai unsur kesenian. Pada pagelaran wayang kulit dituntut adanya kerjasama yang harmonis baik unsur benda mati maupun benda hidup (manusia). Unsur benda mati yang dimaksud adalah sarana dan alat yang digunakan dalam pagelaran wayang kulit. Sementara unsur benda hidup (manusia) adalah orang-orang yang berperan penuh dalam seni pagelaran wayang kulit. Dua unsur tersebut, antara lain:

\section{Unsur Benda}

Unsur benda yang ada dalam pagelaran wayang kulit adalah alat-alat yang berupa benda tertentu yang digunakan dalam pagelaran wayang tersebut. Bahkan terdapat unsur materi yang harus ada (karena tidak bisa digantikan). Unsur materi yang dimaksud antara lain: wayang yang terbuat dari kulit lembu, kelir, debog (batang pohon pisang), seperangkat gamelan, keprak, kepyak, kotak wayang,

${ }^{10}$ Bambang Murtiyoso, Pertumbuhan dan Perkembangan Seni Pertunjukan Wayang, (Surakarta: Etnika Surakarta, 2004), 1 
cempala, dan blencong. Seperangkat alat tersebut harus ada, karena alat-alat tersebut tidak bisa digantikan. Akan tetapi pada perkembangan zaman ada modifikasi atau pengubahan yang dibuat berdasar kebutuhan atau kreatifitas seniman, namun keberadaan wayang dan kelir tidak bisa ditinggalkan.

\section{a. Wayang kulit}

Di Jawa, wayang tentunya terbuat dari kulit. Pada umumnya terbuat dari kulit sapi namun ada juga yang dibuat dari kulit kambing yang sudah diproses menjadi kulit lembaran. Setiap perbuah wayang membutuhkan sekitar ukuran 50 x $30 \mathrm{~cm}$ kulit lembaran. Proses pembuatannya pun cukup lama, mulai dari direndam lalu di gosok terus dipentang supaya tidak kusut kemudian dibersihkan bulu-bulunya, yang kemudian dipahat dengan peralatan yang digunakan adalah besi berujung runcing berbahan dari baja yang berkualitas. Besi baja ini dibuat terlebih dahulu dalam berbagai bentuk dan ukuran, ada yang runcing, pipih, kecil, besar dan bentuk lainnya yang masing-masing mempunyai fungsinya berbeda-beda.

Namun pada dasarnya, untuk menata atau membuat berbagai bentuk lubang ukiran yang sengaja dibuat hingga berlubang. Selanjutnya dilakukan pemasangan bagian-bagian tubuh seperti tangan, pada tangan ada dua sambungan, lengan bagian atas dan siku, cara menyambungnya dengan sekrup kecil yang terbuat dari tanduk kerbau atau sapi. Tangkai yang fungsinya untuk menggerak bagian lengan yang berwarna kehitaman juga terbuat berasal dari bahan tanduk kerbau dan warna keemasannya umumnya dengan menggunakan prada yaitu kertas warna emas yang ditempel atau bisa juga dengan dibron, dicat dengan bubuk yang dicairkan. Wayang yang menggunakan prada, hasilnya jauh lebih baik, warnanya bisa tahan lebih lama dibandingkan dengan yang bron. Baru setelah itu diberi pula untuk kemudian ditatah sesuai dengan gambar pola, dan terakhir diwarnai. Jadilah wayang hasil kreasi seni pahat dan seni lukis.

\section{b. Gamelan}

Gamelan adalah seperangkat alat musik yang menonjolkan metalofon, gambang, gendang, dan gong. Kata gamelan berasal dari bahasa jawa, gamel, yang berarti memukul atau menabuh. Gamelan terbuat dari kayu dan gangsa, sejenis logam yang dicampur tembaga atau timah dan rejasa. Alat musik pengiring instrumen gamelan terdiri dari kendang, bonang, penerus, gender, gambang, suling, siter, clempung, slethem, demung, saron, kenong, kethuk, japan, kempyang, kempul, peking, dan gong. Gamelan yang dipakai untuk mengiringi pertunjukan wayang memiliki nada seru slendro dan pelog. Gamelan dimainkan secara bersama-sama membentuk alunan musik yang biasa disebut gending. Inilah seni kreasi musik dalam pagelaran wayang. 


\section{c. Kelir}

Merupakan sebuah layar lebar yang digunakan pada pertunjukan wayang kulit. Pada rumah Joglo, kelir di pasang pada bagian "pringgitan". Bagian ini merupakan bagian peralihan dari pada ranah publik, pendopo dengan ranah privat, ndalem atau nggandok. Oleh karena itu penonton wayang kulit yang tergolong keluarga, pada umumnya nonton di bagian dalam ndalem, yang sering dianggep nonton mburi kelir. Nonton di belakang kelir ini memang benar-benar "wewayangan", atau bayang-bayang. Dari sinilah pengaruh blencong yang seolaholah "menghidupkan" wayang akan dapat terlihat. Penonton juga tidak terganggu oleh adanya gamelan. Bagi penonton, mereka menonton didepan kelir, sehingga selain dapat melihat keindahan dari pada peraga wayang itu sendiri, oleh karena tatah dan sunggingnya, berikut simpingannya, juga dapat menyaksikan deretan pesinden atau waranggana.

\section{d. Debog}

Adalah batang pisang yang digunakan untuk menancapkan wayang (simpingan). Di simping artinmya dijajar. Baik yang dimainkan maupun yang yang dipamerkan, digunakan "debog". Barang tentu untuk menancapkan wayang yang dipamerkan juga ada aturan-aturan tertentu. Mana wayang yang harus ada disebelah kanan, mana pula yang harus berada disebelah kirinya sang dalang. Tugas menyimping ini sesungguhnya tidak terbatas hanya memasang wayang yang harus dipamerkan, tetapi juga mempersiapkan segala sesuatu keperluan dalang. Misalnya menyediakan wayang-wayang yang akan digunakan sesuai urutan adegan jalannya cerita, menempatkan kotak wayang berikut keprak dan kepyaknya, menyediakan cempala, memasang dan menyalakan maupun mengatur sumbu blencong, lampu minyak yang khas digunakan dalam pertunjukan wayang kulit.

e. Blencong

Adalah lampu minyak kelapa (lenga klentik) untuk menerangi gawang kelir. Dahulu lampu terbuat dari tembaga berbahan bakar sumbu dan minyak kelapa. Blencong didesain khusus, dengan cucuk (paruh) dimana diujungnya akan menyala api sepanjang malam. Oleh karenanya seorang penyimping harus mewaspadai pula keadaan sumbu blencong tersebut manakala meredup, atau bahkan mati sama sekali. Tidak boleh pula api itu berkobar terlampau besar, karena akan mobat-mabit. Kalaupun lampu penerangan untuk dalang pada masa sekarang sudah menggunakan listrik, sesungguhnya ada fungsi dasar yang hilang atau dihilangkan dari penggunaan blencong tersebut. Oleh karena blencong adalah lampu minyak, maka apinya akan bergoyang manakala ada gerakan-gerakan wayang, lebih-lebih waktu perang, yang digerakkan oleh ki dalang. Ada kesan bahwa ayunan api (kumlebeting agni) dari blencong itu seolah-olah memberikan nafas dan atau menghidupkan wayang itu sendiri. Hal yang tak terjadi manakala penerangan 
menggunakan listrik atau (petromax). Saat ini blencong sudah jarang digunakan dan dianggap kurang praktis dan merepotkan.

\section{f. Kotak wayang}

Adalah tempat untuk menaruh wayang yang berbentuk kotak dan terbuat dari kayu, juga digunakan oleh dalang untuk dodogan yang berfungsi memberi aba-aba pada pengiring dan menggambarkan suasana adegan. Kotak wayang berukuran 1,5 meter kali 2,5 meter ini akan merupakan peralatan dalang selain sebagaimana sudah diutarakan merupakan tempat menyimpan wayang, juga sebagai "keprak", sekaligus tempat menggantungkan "kepyak". Dari kotak tempat menyimpan wayang ini juga akan dikeluarkan wayang, baik yang akan ditampilkan maupun yang akan disimping. Disimping artinya dijajar, dipamerkan di kanan dan kiri layar (kelir) yang ditancapkan di debog (batang pisang). Kotak akan ditaruh dekat dalang, di sebelah kiri, dan ditentang yang dekat dalang ditempatkan kepyak. Sedang kepraknya justru bagian dari kotak yang dipukul dengan cempala. Keprak adalah suara dhodhogan sebagai tanda, disebut sasmita, dengan jenis tertentu diwujudkan pemukulan pada kotak dengan menggunakan cempala. Sementara pada kepyak, berupa tiga atau empat lempengan logam (kuningan) yang digantungkan pada kotak, juga dipukul dengan cempala, dalam bentuk tanda tertentu, juga sebagai sasmita atau tanda-tanda untuk mengatur perubahan adegan, merubah, mempercepat, memperlambat, sirep, menghentikan atau mengganti lagu (gendhing). Terdengar nada yang berbeda antara kepyak wayang kulit Jogya dan Surakarta.

\section{g. Cempala}

Adalah suatu peralatan yang digunakan para dalang dihampir semua pertunjukan wayang, yang berfungsi untuk memukul-mukul kotak wayang. Cempala dibuat dari kayu dengan bagian pegangan dan bagian pemukul yang bentuknya membulat. Kayu yang digunakan sebagai pembuat cempala harus kuat dan berat. Biasanya dibuat dari kayu mahoni, nangka, sono, galih asem. Pada zaman dahulu selain terbuat dari kayu, ada yang menggunakan cempala dari tanduk kerbau. Cempala merupakan piranti sekaligus senjata bagi dalang untuk memberikan segala perintah, baik kepada wiraniyaga, wiraswara maupun waranggana. Bentuknya sangat artistik, bagaikan meru. Cempala dipukulkan pada kotak, sebagai keprak, bisa pula ke kepyak, tiga/empat lempengan logam yang digantungkan pada kotak wayang. Pada saat ke dua tangan dalang sedang memegang wayang dan ini yang unik maka tugas untuk membunyikan keprak maupun kepyak, dengan tetap menggunakan cempala, dilakukan oleh kaki kanan ki dalang. Cempala dengan desain sedemikian rupa itu akan dijepit di antara ibu jari dan jari telunjuk berikutnya. Menggunakan cempala memerlukan latihan untuk 
memperoleh tingkatan ketrampilan tertentu. Memukul kotak dengan cempala, dalang dapat memilih berbagai kemungkinan pembangun suasana dengan dhodhogan, seperti ada-ada, pathetan, kombangan. Dapat pula sebagai perintah kepada karawitan untuk mengawali, merubah, sirep, gesang atau menghentikan gamelan. Juga dapat digunakan untuk memberikan ilustrasi adegan, seperti suara kaki kuda, suara peperangan dan lain-lain. Artinya, ketika ke dua belah tangan ki dalang sedang memainkan wayang, maka keprak atau kepyak dapat juga berbunyi. Suatu keprigelan yang jarang dapat dilihat oleh para penonton wayang, karena biasanya ia sedang asyik mengikuti adegan yang ditampilkan di kelir (layar). Padahal untuk mencapai tingkat keprigelan tersebut, seorang dalang harus melakukan latihan-latihan yang intensif. Betapa tidak, keempat anggota badan, tangan dan kaki harus terus bergerak, sementara pikiran dan pandangan terfokus pada apa yang dilakukannya di layar (kelir).

\section{h. Panggung}

Adalah tempat yang agak tinggi terbuat dari papan untuk menaruh peralatan wayang dan gamelan. Panggung bukan kebutuhan yang pokok karena pada hakekatnya pertunjukan bisa dilakukan dimana saja asalkan tempatnya cukup dan nyaman contoh di hotel, studio, pendapa dan sebagainya.

\section{i. Soundsystem}

Adalah peralatan elektronik untuk mengeraskan suara dalang dan gamelan. Sounsistem bukan kebutuhan pokok karena kalau tanpa soundsistempun bisa berjalan cuma dengan volume yang kecil.

\section{Unsur Manusia}

Dalang, penyimping, penabuh, dan sinden adalah orang-orang yang berperan penting dalam kelancaran dan keberhasilan sebuah pagelaran wayang. Mereka adalah orang-orang yang memiliki kemahiran khusus dalam bidangnya masingmasing. Berkat kemahiran khusus tersebut, terkadang mereka tidak bisa digantikan oleh sembarang orang. Peranan dalang sangat penting dan paling menentukan bagi perkembangan dunia pewayangan ${ }^{11}$.

\section{a. Dalang}

Dalang adalah pengatur jalannya pertunjukan wayang. Dalam pertunjukan wayang kulit, dalang adalah bagian terpenting. Dalang berasal dari akronIm ngudhal piwulang. Kata ngudhal berarti membongkar atau menyebar luaskan dan piwulang berarti ajaran, pendidikan, ilmu, informasi. Jadi fungsi dalang dalam

${ }^{11}$ Wawan Susetya, Dalang, Wayang dan Gamelan, (Jakarta: Narasi, 2007), 28. 
pergelaran wayang kulit bukan saja pada segi pertunjukan atau hiburan, namun juga harus memberi tuntutan. Dalang harus menguasai teknik pedalangan sebagai aspek hiburan, juga berpengetahuan luas dan mampu memberikan pengaruh. Fungsi dalang adalah orang yang memberi penerangan dan bimbingan bagi masyarakat yang tingkat sosialnya beranekaragam ${ }^{12}$.

Selain itu dalang merupakan sutradara, pemain, artis, serta tokoh sentral dari pada suatu pertunjukan wayang. Tanpa dalang, maka pertunjukan wayang itu tidak akan berjalan. Apalagi untuk dalang pada pertunjukan wayang kulit. Komunikasi antara dalang dengan unit pendukung, perlengkapan dan peralatan pertunjukan wayang merupakan komunikasi yang unik. Melalui segenap indera yang dimilikinya, ia berkomunikasi dengan kompleksitas orang dan peralatan yang lazim digunakan dalam suatu pertunjukan wayang. Tanpa suatu skenario yang dipersiapkan terlebih dahulu, namun wayang tampil secara spontan, kompak dan tidak pernah mengalami kesalahan semalam suntuk. Sungguh suatu bentuk teater yang aneh karena meskipun tanpa suatu skenario padahal dalang dapat memilih beratus lakon atau cerita baku (babon pakem), carangan, anggitan (sanggit) tontonan dapat berjalan mulus dari jejeran sampai tancep kayon. Sebagai figur utama sudah sewajarnya dapat tampil dalam berbagai peranan, sebagai komunikator, seniman, pendidik masyarakat, penghibur maupun kritikus sosial ${ }^{13}$.

\section{b. Penyimping}

Adalah orang yang membantu dalang dalam menyiapkan wayang yang di jajar (disimping) pada debog . Tugas menyimping ini sesungguhnya tidak terbatas hanya memasang wayang yang harus dipamerkan, akan tetapi juga mempersiapkan segala sesuatu keperluan dalang. Misalnya menyediakan wayang-wayang yang akan digunakan sesuai urutan adegannya, menempatkan kotak wayang berikut keprak dan kepyaknya, menyediakan cempala, memasang dan menyalakan maupun mengatur sumbu blencong, lampu minyak yang khas digunakan dalam pertunjukan wayang kulit, dan lain-lain. Sekali-sekali juga membantu pelayanan konsumsi (makan minum, rokok) untuk dalang. Untuk penyiapan ini terkadang dibantu oleh anak-anak muda sebagai salah satu media pendidikan untuk mengenali dan akhirnya mencintai budaya wayang.

\section{c. Panjak (Nayaga/Pengrawit)}

Adalah penabuh gamelan jawa disebut panjak, nayaga atau pengrawit. Nayaga atau yaga berasal dari kata wiyaga yang berarti semedi atau meditasi.

12 Yoyo Rismayan, Tuntunan Praktek Pedalangan Wayang Golek Purwa Gaya Sunda, (Bandung: STSI, 1983), 24.

13 Victoria Groenendael, Dalang di Balik Wayang, (Jakarta: Pustaka Utama Grafiti, 1987), 55. 
Dalam menjalankan tugas menabuh gamelan, seorang nayaga menabuh dengan konsentrasi dengan tujuan untuk memberi roh terhadap gending yang sedang dimainkan. Keseriusan tersebut seperti seorang yang sedang bersemedi. Sedangkan pengrawit berasal dari kata rawit, yang berarti rumit. Pengrawit memang selalu berhadapan dengan hal-hal rumit, misalnya harus menghapal ratusan gending yang berbentuk not-not angka di luar kepala dan menyajikannya dengan baik dan benar.

Orang-orang yang bertugas sebagai penabuh gamelan harus mempunyai kemahiran khusus dalam memainkan lagu (gendhing) sesuai dengan permintaan dalang. Permintaan dalang tentunya tidak verbalistik, namun penabuh gamelan diharuskan memahami isi cerita/lakon wayang dan gendhing yang dimainkan hendaknya diselaraskan dengan lakon cerita wayang. Hal inilah menuntut ketajaman intuisi bagi penabuh gamelan dalam pagelaran wayang, karena dalam pagelaran wayang tidak disediakan notasi musik dalam memainkan gamelan. Semuanya menggunakan intuisi seniman. Setiap kali menjalankan tugas mengiringi pertunjukan wayang, para nayaga selalu berpakaian resmi, yaitu pakaian tradisional dengan baju beskap, kain jarit dan blankon (ikat kepala dari bahan batik).

d. Waranggana (pesinden)

Pesinden juga sering disebut sinden, berasal dari kata pasindhian yang berarti yang kaya akan lagu atau yang melagukan (melantunkan lagu). Sinden juga disebut waranggana, yang berasal dari kata wara yang berarti seseorang yang berjenis kelamin wanita, dan anggana berarti sendiri. Pada zaman dahulu, waranggana adalah satu-satunya wanita dalam pergelaran wayang ataupun pentas klenengan. Setiap menjalankan tugas, pesinden harus berpakaian resmi, memakai kain kebaya, rambut digelung atau di sanggul. Mereka harus duduk bersimpuh (duduk di lantai dengan posisi kaki dilipat). Posisi duduk bersimpuh merupakan posisi duduk yang di anggap sopan manakala menghadapi seseorang yang dihormati. Pesinden haruslah mempunyai suara yang khas sebagai pesinden, yaitu suara yang melengking merdu dengan cengkok suara yang luwes. Mereka harus hafal tembang-tembang tradisional lama dan baru, namun juga ketahanan fisik yang prima. Hal ini diperlukan karena biasanya pagelaran wayang kulit itu dilaksanakan semalam suntuk. Tentu harus mempunyai fisik yang sehat dan kuat untuk melantunkan lagu-lagu jawa serta menahan kantuk mulai senja hingga pagi hari.

\section{Makna Filosofi Wayang Sebagai Media Dakwah}

Wayang sebagai media yang tepat untuk melakukan dakwah Islam waktu itu sesuai dengan budaya lokal masyarakat setempat. Wayang merupakan budaya warisan leluhur, yang mampu bertahan dan berkembang sampai saat ini. Dengan mengalami perubahan dan perkembangan sampai mencapai bentuknya yang sekarang ini, sesuai tuntutan zaman. Wayang juga dikenal sebagian besar masyarakat Jawa, memiliki corak, bentuk yang khusus dan bermutu tinggi. Wayang 
digunakan sebagai pendekatan media dakwah karena merupakan kesenian tradisional yang paling digemari oleh masyarakat. Selain itu juga mempunyai peranan sebagai alat pendidikan serta komunikasi langsung dengan masyarakat yang dipandang efektif dapat dimanfaatkan untuk penyiaran agama Islam.

Pada abad 17 ditanah Jawa, di kenal walisongo sebagai penyebar agama Islam. Mereka tinggal di tiga wilayah penting pantai utara Pulau Jawa, yaitu Surabaya, Gresik, Lamongan di Jawa Timur, Demak, Kudus, Muria di Jawa Tengah, dan Cirebon di Jawa Barat. Walisongo terdiri dari sembilan orang, yaitu: Maulana Malik Ibrahim, Sunan Ampel, Sunan Bonang, Sunan Giri, Sunan Kudus, Sunan Drajat, Sunan Muria, Sunan Gunung Jati, dan Sunan Kalijaga. Kesembilan wali yang dalam bahasa Arab artinya "penolong" ini merupakan para intelektual yang terlibat dalam upaya pembaharuan sosial yang pengaruhnya terasa dalam berbagai apek kebudayaan, yang menarik dari kiprah para walisongo ini adalah aktivitas mereka menyebarkan Islam di nusantara tidaklah dengan armada militer, tidak juga dengan menindas keyakinan lama yang dianut oleh masyarakat Indonesia yang saat itu mulai memudar pengaruhnya, Hindu dan Budha. Namun mereka melakukan perubahan sosial secara halus dan bijaksana, seperti halnya Islam yang mengajarkan kehalusan tanpa kekerasan. Mereka tidak langsung menentang adat kebiasaan-kebiasaan lama masyarakat, namun menjadikannya sebagai sarana dalam dakwah. Salah satu sarana yang mereka gunakan sebagai media dakwah mereka adalah wayang. Para wali melakukan berbagai penyesuaian dengan adat setempat agar lebih sesuai dengan ajaran Islam. Bentuk wayangpun diubah yang awalnya berbentuk menyerupai manusia menjadi bentuk yang baru. Wajahnya miring, leher dibuat memanjang, lengan memanjang sampai kaki dan bahannya terbuat dari kulit kerbau. Dalam hal esensi yang disampaikan dalam cerita-ceritanya tentunya disisipkan unsur-unsur moral keIslaman. Dalam lakon Bima Suci misalnya, Bima ${ }^{14}$ sebagai tokoh sentralnya diceritakan menyakini adanya Tuhan Yang Maha Esa. Tuhan Yang Esa itulah yang menciptakan dunia dan segala isinya. Tak berhenti di situ, dengan keyakinannya itu Bima mengajarkannya kepada saudaranya, Arjuna. Lakon ini juga berisi ajaran-ajaran tentang menuntut ilmu, bersikap sabar, berlaku adil, dan bertatakrama dengan sesama manusia ${ }^{15}$. Cerita ini sangat bagus dan sangat digemari di kalangan kasepuhan karena mengandung perenungan mendalam tentang asal dan tujuan hidup manusia (sangkan paraning dumadi) dan menjawab

${ }^{14}$ Bima adalah seorang tokoh protagonis dalam wiracarita Mahabharata. Ia merupakan putra Kunti, dan dikenal sebagai tokoh Pandawa yang kuat, bersifat selalu kasar dan menakutkan bagi musuh, walaupun sebenarnya berhati lembut

15 Aep Kusnawan, Ilmu Dakwah: Kajian Beberapa Aspek, (Bandung: Pustaka Bani Quraisy, 2012), 7. 
kerinduan hidup dalam perjalanan rohani orang Jawa untuk bersatu dengan Tuhan (manunggaling kawulo Gusti atau curiga manjing warangko). Cerita atau kisah pewayangan merupakan salah satu karya sastra Jawa yang berperan besar dalam hidup atau daur hidup orang Jawa ${ }^{16}$. Orang Jawa biasanya menggunakan kisah pewayangan sebagai sarana mengkomunikasikan pesan-pesan bijaksana, moral, etika, dan nilai-nilai filosofis. Selain itu, menampilkan salah satu kisah pewayangan dipercaya dapat menghindarkan seseorang atau keluarga dari Betara Kala yang bisa mendatangkan ketidakberuntungan dan marabahaya ${ }^{17}$.

Selain itu kesenian wayang mempunyai peran yang cukup besar dalam proses pengislaman di Jawa, sebetulnya wayang sendiri merupakan peninggalan agama Hindu, namun para wali dapat berfikir rasional. Mereka sadar bahwa pertunjukan wayang telah berakar kuat di masyarakat dan tidak mungkin untuk dihilangkan begitu saja. Maka para wali, termasuk Sunan Kalijaga, mempunyai inisiatif untuk merubah, membesut, dan menyempurnakan wayang, lalu diisi dengan nilai-nilai Islam, moral, budi luhur yang bernafas keIslaman. Lewat media wayang, Sunan Kalijaga dinilai berhasil dalam berdakwah melalui media wayang. Unsur baru berupa ajaran Islam dimasukkan dalam unsur pewayangan. Hal ini dilakukan agar masyarakat yang menonton dapat menerima ajaran Islam dengan sukarela dan mudah, tanpa adanya paksaan. Masyarakat Jawa yang masih mengagungkan nilainilai budaya akan lebih menerima nilai keagaman jika penyampaiannya itu lebih bersifat halus, sesuai dengan psikologi masyarakat Jawa yang lebih mengedepankan kehalusan budi dibandingkan jika pengajaran itu disampaikan dengan cara-cara indoktrinisasi ekstrem.

Walisanga banyak memperkenalkan ajaran-ajaran Islam (aqidah, syari'ah, dan akhlaq) melalui alur cerita yang dibangun berdasarkan perilaku punakawan tersebut, misalnya: Sunan Kalijaga, dalam menyelenggarakan pertunjukan wayang, selalu memilih tempat yang tidak jauh dari Masjid. Di sekeliling tempat pagelaran wayang, Sunan Kalijaga lalu membuat parit yang mengalir di dalamnya air yang jernih. Parit ini dibuat untuk melatih para penonton wayang agar mencuci kaki sebelum masuk masjid. Di tangan Sunan Kalijaga, wayang yang terbuat dari kulit kerbau itu ditransformasikan menjadi wayang kulit yang bercorak Islami. Sunan Kalijaga menciptakan tokoh punakawan sebagai sarana untuk menyebarkan agama Islam di tanah Jawa. Semar (meski sudah ada sejak masa kerajaan Majapahit) diperkirakan berasal dari bahasa Arab, yaitu simaar atau ismarun yang berarti paku. Paku adalah alat untuk menancapkan suatu barang agar tegak dan kuat. Ismaya

\footnotetext{
${ }^{16}$ Marbangun Hardjowirogo, Manusia Jawa, (Jakarta: CV Haji Masagung, 1999), 41.

${ }^{17}$ Sri Mulyono, Wayang dan Filsafat Nusantara, (Jakarta: PT Gunung Agung, 1982), 79.
} 
merupakan nama lain Semar yang berasal dari kata asma-Ku atau simbol kemantapan dan keteguhan. Selanjutnya, Nara Gareng berasal dari kata naala qarin yang artinya memperoleh banyak kawan. Petruk diadaptasi dari kata faruk yang artinya tinggalkan yang jelek.

Hadirnya tokoh panakawan ${ }^{18}$ (semar, gareng, petruk, bagong) dalam pewayangan sengaja diciptakan, untuk memperkuat konsep filsafat bahwa di dunia ini tidak ada makhluk yang benar-benar baik, dan jahat. Setiap makhluk selalu menyandang unsur kebaikan dan kejahatan dalam dirinya. Filsafat dan wayang satu kesatuan utuh dan keduanya tidak dapat dipisahkan. Berbicara tentang wayang berarti kita telah berfilsafat karena wayang merupakan filsafat Jawa. Karena wayang mengambil ajaran-ajarannya dari sumber sistem-sistem kepercayaan, dan menawarkan berbagai macam filsafat hidup yang bersumber pada sistem-sistem kepercayaan tersebut. Hidup haruslah berdasarkan kepada apa yang dinamakan kebenaran. Dan menurut wayang, "kebenaran sejati" (ultimate truth) datangnya hanyalah dari Tuhan. Untuk mendapatkan ini, manusia harus dapat mencapai "kesadaran sejati" (ultimate awareness) dan memiliki "pengetahuan sejati" (ultimate knowledge). Untuk itu, manusia harus dapat melihat "kenyataan sejati" (ultimate reality) dengan melakukan dua hal. Pertama, mempersiapkan jiwa raganya sehingga menjadi manusia yang kuat dan suci, dan kedua memohon berkah Tuhan. Nilai-nilai filosofi yang terdapat dalam cerita pewayangan selalu mengajak masyarakat untuk berbuat baik dan menghindari kejahatan, serta menanamkan kepada masyarakat semangat "amar ma'ruf nahi mungkar" atau istilah dalam pewayangan "memayu hayuning bebrayan agung", sesuai dengan ajaran agama dan kepercayaan masing-masing.

\section{Kesimpulan}

Dari uraian pembahasan tersebut diatas ada beberapa kesimpulan yaitu sebagai berikut:

1. Wayang berasal dari kata Ma Hyang yang berarti menuju kepada roh spiritual, dewa atau Tuhan Yang Maha Esa. Wayang kulit adalah walulang inukir (kulit

${ }^{18}$ Istilah panakawan berasal dari kata pana yang bermakna "paham", dan kawan yang bermakna "teman". Maksudnya ialah, para panakawan tidak hanya sekadar abdi atau pengikut biasa, namun mereka juga memahami apa yang sedang menimpa majikan mereka. Bahkan seringkali mereka bertindak sebagai penasihat majikan mereka tersebut. Hal yang paling khas dari keberadaan panakawan adalah sebagai kelompok penebar humor di tengah-tengah jalinan cerita. Tingkah laku dan ucapan mereka hampir selalu mengundang tawa penonton. Selain sebagai penghibur dan penasihat, adakalanya mereka juga bertindak sebagai penolong majikan mereka di kala menderita kesulitan. 
yang diukir) dan dilihat bayangannya dari kelir. Wayang kulit sebagaimana adanya sekarang merupakan kreasi wali songo, khususnya Sunan Bonang dan Sunan Kalijaga, dari membaca alam lingkungan masyarakat Jawa yang telah tumbuh sebelumnya, menggunakan wayang guna menyebarkan ajaran Islam karena masyarakat yang saat itu sangat menyenangi wayang. Kreatifitas para wali memanfaatkan budaya setempat sebagai media penyebaran Islam yang efektif tersebut, telah mempercepat pertumbuhan dan perkembangan Islam di Jawa. Selain itu para wali juga berjasa dalam mempopulerkan seni wayang sebagai bentuk kesenian pentas yang merupakan salah satu kekayaan budaya Indonesia yang telah berakar jauh ke masa lalu dan cukup banyak mengalami pertumbuhan dan penyempurnaan dari masa ke masa.

2. Ada dua unsur dalam perlengkapan wayang kulit, yaitu:

Unsur benda terdiri dari: wayang kulit, gamelan, kelir, debog, blencong, kotak wayang, cempala, panggung, soundsistem. Sedangkan dari unsur manusia, terdiri dari: dalang, penyimping, panjak, waranggana.

3. Wayang merupakan bagian dari filsafat karena wayang mengambil ajaranajarannya dari sumber sistem kepercayaan, dan menawarkan berbagai macam filsafat hidup yang bersumber pada sistem-sistem kepercayaan tersebut. Hidup haruslah berdasarkan kepada apa yang dinamakan kebenaran. Dan menurut wayang, "kebenaran sejati" (ultimate truth) datangnya hanyalah dari Tuhan. Untuk mendapatkan ini, manusia harus dapat mencapai "kesadaran sejati" (ultimate awareness) dan memiliki "pengetahuan sejati" (ultimate knowledge). Nilai-nilai filosofi yang terdapat dalam cerita pewayangan selalu mengajak masyarakat untuk berbuat baik dan menghindari kejahatan.

\section{Daftar Pustaka}

Amir, Hazim. 1991. Nilai-Nilai Etis dalam Wayang. Jakarta: CV. Mulia Sari.

Bastomi, Suwaji. 1993. Nilai-Nilai Seni Pewayangan. Semarang: Dahara Prize.

Budi, Setyo. 2002. Wayang-Wayang Katolik Surakarta: Spesifikasi dan Karakteristiknya. (Bandung: Proyek Penelitian Pendidikan Tinggi Direktorat Jenderal Pendidikan Tinggi Departemen Nasional).

Dawud, Mochammad. Menerapkan Manajemen Strategi Penyiaran untuk Penyiaran Dakwah. Jurnal Al-Hikmah, 2019, 17.1: 109-140.

Elanda, Yelly. Komodifikasi Agama pada Perumahan Syariah di Surabaya. Jurnal Al-Hikmah, 2019, 17.1: 41-62.

Guritno, Pandam. 1988.Wayang, Kebudayaan Indonesia dan Pancasila. Jakarta: UI 
Press.

Groenendael, Victoria. 1987. Dalang di Balik Wayang. Jakarta: Pustaka Utama Grafiti.

Hardjowirogo, Marbangun. 1999. Manusia Jawa. Jakarta: CV Haji Masagung.

Haryanto. 1992. Bayang-Bayang Adiluhung. Semarang: Dahara Prize.

Hadi, H. Sofyan. Manajemen Strategi Dakwah di Era Kontemporer. Jurnal AlHikmah, 2019, 17.1: 79-90.

Isfironi, Mohammad. Kota Santri, Bumi Shalawat Nariyah dan Bule-Dhika. Jurnal Al-Hikmah, 2019, 17.1: 1-20.

Jannah, Hasanatul. Pondok Pesantren Sebagai Pusat Otoritas Ulama Madura. Jurnal Al-Hikmah, 2019, 17.1: 91-108.

Kusnawan, Aep. 2012. Ilmu Dakwah : Kajian Beberapa Aspek. Bandung: Pustaka Bani Quraisy.

Mulyono, Sri. 1976. Asal-Usul Filsafat dan Masa Depannya. Jakarta: Gunung Agung.

Mulyono, Sri. 1982. Wayang dan Filsafat Nusantara. Jakarta: PT Gunung Agung.

Murtiyoso, Bambang. 2004. Pertumbuhan dan Perkembangan Seni Pertunjukan Wayang. Surakarta: Etnika Surakarta.

Rismayan, Yoyo. 1983. Tuntunan Praktek Pedalangan Wayang Golek Purwa Gaya Sunda. Bandung: STSI.

Salam, Solichin. 1960. Sekitar Wali Sanga. Jakarta: Menara Kudus.

Sofwan, Ridin. 2004. Merumuskan Kembali Interelasi Islam-Jawa. Yogyakarta: Gama Media.

Susetya, Wawan. 2007. Dalang, Wayang dan Gamelan. Jakarta: Narasi.

Wazis, Kun. Perlawanan Ahli Hadis terhadap Gerakan Radikalisme Dalam Konstruksi Media Online. Jurnal Al-Hikmah, 2019, 17.1: 20-40. 